\title{
Constitutionalizing Power: How Do Rules Legitimize the Executive?
}

\author{
Ekaterina R. Rashkova ${ }^{1}$
}

\begin{abstract}
Reflecting upon recent political events, attention toward political legitimacy has been renewed within political science debate. However, the concept remains rather broad and elusive with few attempts to find a common way to measure it. An increasing number of scholars have recently examined the link between party regulation and political legitimacy. Building on this research, the current paper explores the role of regulation in legitimizing power. In particular, this project studies how rules endorse leaders. The paper discusses extant measurements of legitimacy and offers a new one. The new measure, Executive Legitimizing Index (ELI), is based on content analysis of constitutional texts in 30 European democracies and emphasizes the power that regulations give to the public to control the executive branch. The paper develops the index both conceptually and empirically and shows that there are significant differences in executive regulation among four pre-defined groups of democracies.
\end{abstract}

Key words: political legitimacy, constitutions, executive, regulation, Europe

Where power is acquired and exercised according to justifiable rules, and with evidence of consent, we call it rightful or legitimate. These were amongst the opening words in Beetham's (1991) influential book The Legitimation of Power, which is one of the first attempts to develop the concept of legitimacy in a social scientific manner. Legitimacy has been an issue that has occupied the minds of philosophers for a time longer than it has been written about in the academic literature, yet, at its very core it still remains a concept we know little about. Despite its widespread occurrence, which has been considerably heightened in the months leading up to this writing, legitimacy remains a somewhat vague and elusive concept, certainly one that cannot claim to have inspired a consensus over its meaning. Therefore, we still have to ask ourselves the question 'what is legitimacy' and how do we know it? How is legitimacy achieved and retained in politics? More importantly, what legitimizes power?

These are some of the pressing questions that political entrepreneurs, institutional engineers and political scientists ought to be busy trying to answer. A day does not go by without news about strikes or protests taking place in some part of the world. Biezen and Wallace (2013) rightfully observe that 'one

${ }^{1}$ Ekaterina R. Rashkova, School of Governance, Utrecht University, Bijlhouwerstraat 6, 3511 ZC, Utrecht, the Netherlands, email: e.rashkova@uu.nl. 
feature of contemporary politics across much of Europe is that there seems to be increasing evidence of contention and of contrariness' (294). Political contention is in fact a phenomenon which spreads far beyond Europe. Consider the recent political events in Turkey, the ongoing US presidential campaign, or the student close-out of universities in South Africa . . These events, as different as they may be, have one characteristic in common - they put the questions 'what is legitimacy' and 'what legitimates power' to the forefront.

The majority of extant works studying some aspect of legitimacy focus on the first question. Here, the emphasis is on the second. Departing from Beetham's multi-dimensional framework of legitimacy - one based on legality, justifiability and consent - the paper aims to illuminate the link between legality and justifiability, and more specifically discuss the extent to which rules justify the practices of political leaders. Taking up the case of the executive branch, this study examines the conditions which bind executive decisions as listed in the highest national law. Starting from the premise that what legitimates power is the control that the people retain upon their chosen leaders, the paper examines and codes the constitutions of thirty European democracies. The idea is that it is the people who legitimate their leaders and therefore a first step to conceptualizing legitimation is to establish the different ways in which citizens bestow power upon their leaders, or in other words 'how far or close' citizens are from their leaders. The paper offers an originally developed measure of legitimation, based on seven categories of rules, which have been identified as being the building blocks of closeness of the people to their leaders. Acknowledging the advantages and disadvantages of building aggregate measures, and their respective imperfections, the paper makes a conceptual contribution to the measurement of one aspect of legitimacy - legitimation, and offers the executive legitimation index (ELI), which takes our attempt to understand, and quantify, legitimacy, a step further.

The paper proceeds as follows. The next section introduces the literature on political legitimacy and regulation and establishes a link between the two. Section two discusses the constitutionalization of the executive in comparative perspective in more detail and offers the 'raw' data, which has been collected for the execution of this research. Section three discusses the coding techniques and the construction of the index and presents preliminary empirical results. The paper ends with a brief discussion of the index and some concluding remarks. 


\section{POLITICAL LEGITIMACY AND REGULATION}

The sweeping wave of some form of protest, which we have recently observed in the world, constitutes what Beetham referred to as delegitimation. He writes that acts 'ranging from non-cooperation and passive resistance to open disobedience and military opposition on the part of those qualified to give consent will in different measure erode legitimacy, and the larger the numbers involved, the greater the erosion will be' $(1991,19)$. Therefore, for Beetham, the protests having taken place in different parts of the world recently, are not only an expression of interest or a plead for change, they are actions clearly stating that in the eyes of those protesting, the powerful have lost power, i.e. have become illegitimate.

What is legitimacy and how do we know it? The difficulty in defining and conceptualizing what precisely legitimacy is, are some of the primary reasons for the generally few attempts to quantify the concept. In an attempt to contribute to solving this, and offer a way in which we can measure one aspect of legitimacy, in this paper, we perceive of legitimacy as constituting of three components that of legitimation, that of delivery, and that of evaluation - as shown in Figure 1. All three of them contribute to the level of legitimacy in a particular state. The first part - legitimation - is the part in which the people, through their elected representatives, entrust the government and its functions, while retaining the ability to overthrow it. This part involves 'the rules of the game', and is the part of legitimacy that this study is concerned with. The second part - delivery contains everything related to the 'use' of this entrustment, and we conceive of it essentially as the space (and action) between what governments promise and what governments deliver. Lastly, the third part - evaluation - is the part of the public sentiments about a given government. These are often studied through survey questions, which examine the extent to which people trust and agree with their government's choices. The result of people's evaluation of those that rule them, is their ability to exercise the power with which they have entrusted their leaders in the first place - by voting them in or out of office. 
Figure 1: Conceptual vision of what constitutes legitimacy

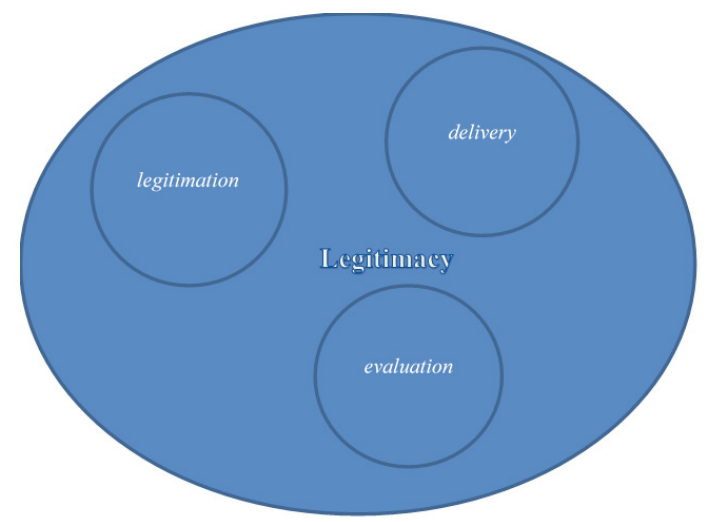

Source: Author's conceptualization.

Working our way back to the origins of the problem of what constitutes legitimacy and how do we know it, a primary question to ask is 'what legitimates power in the first place?'. According to Schmidt (2013), who sets out to evaluate the democratic legitimacy of the European Union, theorists of democracy are divided not only by the response they have to that question, but also by the normative criteria by which they evaluate legitimacy. Some, Beetham included, she argues, focus on the input or what goes on inside EU governance looking at authorization, representation, and accountability, while others amongst whom Moravcsik (2002) and Heritier (1999), base their judgments on the output or the policies which come as a result of EU governance. Schmidt on the other hand, contends that there is still a missing link in the more or less established camps of how we evaluate legitimacy, and that is the idea of the 'black box' as she calls it, or what goes on between the input and the output, something that she introduces as throughput. Stemming from systems theory as Schmidt notes, throughput uses processes such as efficacy and transparency to evaluate the legitimacy of the European Union. The difference between the three is that while input and output can be seen as substitutes, more of one decreases the other, more throughput, i.e. more transparency and involvement of people in the processes of the EU, does not affect neither input nor output, but 'less or worse throughput can delegitimate both input and output' $(2013,19)$. Despite this relationship however, Schmidt admits that no matter how much the EU and national governments seek to enhance the transparency of the inside processes going on at the European Union, throughput legitimacy cannot be a substitute to input legitimacy, but it can complement it in order to achieve higher output legitimacy. 
Challenging the idea that political legitimacy can be achieved via electoral democracy, Rothstein (2009) puts himself firmly against the ability of the input of the political system to create, maintain, or destroy legitimacy. According to him, political legitimacy depends on the quality of government, not the quality of elections or political representation. Yet, one of the major ways in which quality of government can be put to a test, is precisely via democratic elections and representative democracy. Indeed, in his fervent defense of EU's legitimacy, Moravcsik points out that the most fundamental source of legitimacy for the Union lies in the democratic accountability of national governments $(2002,619)$. The latter suggests however, that not only elections, as a source of demonstrable expression of consent are imperative for the selection of national governments, but that the accountability of governments, which Moravscik demarcates as the foundation for increasing the legitimacy of the Union, and thus the judgment of their quality, heavily depend on the initial two conditions to legitimacy that Beetham laid down in his original text - that of legality and justifiability of power.

The problems of legality and justifiability of power have recently been examined by Molenaar (2014), Scherlis (2014), Svasand (2014), Gauja (2014), Ghergina (2014), Casal Bertoa et al. (2014) and Whiteley (2014). While coming from the examination of various aspects of legitimacy and in a number of different contexts ranging from the development of political party regulation in Malawi, to a cross-national study on the effect of trust on party membership in established democracies, these works give a similar message - rules are important, but they do not give the whole story. Rashkova and Biezen (2014) further emphasize that implementing the rules that are already in place and focusing on those rules that affect a specific outcome is what really matters. Building on these works, which have established the existing relationship between party regulation and political legitimacy, this paper shifts the attention from the regulation of political parties to the regulation of those who govern, here broadly termed 'the executive' and the 'feedback link' between them and those who have entrusted them with power. As Moravcsik noted one of main criticisms that proponents of the EU's democratic deficit thesis have, is that as an organization of continental scope it appears distant from the individual European citizen $(2002,604)$. Yet, he has further argued that one of the sources of legitimacy that the European Union has, are the national governments of its member-states, i.e. the leaders, which have been elected in each respective country and therefore, by default, cannot be more close to the people than that. Drawing on this logic and on Beetham's first condition of legitimacy, that of power being legally acquired and exercised within the law $(1991,4)$, this paper examines the link between the people and the 
executive branch of thirty European democracies. It does that by analyzing the rules which constrain the power of those that rule and thus return, to a varying extent, the control over the leaders to the hands of the 'subordinate' - the people.

\section{CONSTITUTIONALIZATION OF THE EXECUTIVE}

The notion that 'institutions matter' is well known among new institutionalists and has been the point of departure for studies for many years. At the same time, it has been only in the last decade that scholars interested in parties and party system development have pointed to the importance of a certain type of institution, in particular that of 'regulation'. Questions that have been studied include rules about the establishment, activity and closure of parties, public and private funding, and party membership. Not much has been done however, to examine the rules that govern the executive branch. Using data from the Party Law in Modern Europe (2013), this paper examines the rules governing the powers of the executive branch, as regulated in national constitutions. Most studies about political legitimacy use survey data and consider the level of trust in the various political institutions as indicative for how legitimate a political regime is. The current paper offers a new way of thinking about and operationalizing political legitimacy, namely by considering the a priori evaluation of the rules which legalize and enable the functioning of these very institutions, rather than the $a$ posteriori question of how people evaluate certain institutions. The latter carries its own importance, but it covers only one part of the concept of 'legitimacy' as indicated in the previous section.

The sample consists of thirty post-war European democracies. ${ }^{2}$ The European states are chosen for two reasons. First, they are the most studied group of countries and thus the current examination has a vast base to link and to contribute to. Second, the European countries provide a wide variation on multiple factors, including the maturity of their democracy, their economic performance, as well as their institutional design.

Beginning with the question 'what legitimates power?', the paper identifies seven characteristics of the design of the executive branch, which affect how 'close' the people are to being in control of how they are governed. Theoretically, the more control people have, where control is meant as the ability to change things, the more legitimate a particular executive branch is. We can embed the argument in the principal-agent theory. The idea here is that the higher control

\footnotetext{
${ }^{2}$ The countries which are included in the sample are-Austria, Belgium, Bulgaria, Croatia, Cyprus, the Czech Republic, Denmark, Estonia, Finland, France, Germany, Greece, Hungary, Iceland, Ireland, Italy, Latvia, Lithuania, Malta, the Netherlands, Norway, Poland, Portugal, Romania, Serbia, Slovakia, Slovenia, Spain, Sweden, and Switzerland.
} 
over removing the executive by the people (the principal), when the latter are dissatisfied with the way in which they are represented and led, increases the legitimation of those who govern (the agent). The reasoning follows the logic that rules offer an incentive structure for a specific behavior. Thus, a set of rules which put the people in control of the destiny of the leader incentivizes the leader to serve the wishes of his/her people, i.e. to represent them. The link between the amount of control people have and the level of representation it incentivizes is where we argue that legitimation happens. Bearing this in mind, data for the following seven indicators of legitimation has been collected-years in office, option to impeach, veto and veto override, direct election, executive decree, number of terms in office, and checks and balances. The main theoretical condition that justifies the selection of the indicators, as opposed to others, as being relevant and valid, is that they all reflect the link between the principal and the agent. Each of the chosen indicators connects the manner (including its length, its authority, its way of being elected) in which the government governs to the electorate, or the people, which have vested power in the said rulers. ${ }^{3}$

The logic behind most of these is straight forward. The years in office indicator signifies that a longer executive term makes it harder for the citizens to change the status quo, and vice versa, a shorter executive term would imply that unsatisfied people can vote the executive out of office sooner, and thus are foreseen to have more control over those who rule. As mentioned earlier, the paper argues that the more control people have over their rulers, the more legitimate power is. Most European states are parliamentary democracies or constitutional monarchies with prime ministers as head of the executive branch; however, there is quite considerable variation in the length of the executive term. ${ }^{4}$ The shortest term of office is that of the Swiss President and Vice President, who are elected from the Federal Council by the national assembly for a term of one year (Art. 176.2, Swiss Constitution). Ireland and Italy, on the other hand, elect their Presidents for a term of seven years (Art. 12. 3. 1, Constitution of Ireland, and Art. 85, ${ }^{3}$ Other conceivable measures, such as transparent decision-making, transparent execution of political decisions, or anti-corruption measures, are considered to pertain more to the second component of legitimacy (that of delivery), as theorized here, and have thus not been included in the index developed by this study. Furthermore, the index of legitimation proposed here, has the task of evaluating the rules that vest power in those who govern as codified in the constitutional texts of various states, and the level of transparency of decision-making or anti-corruption techniques are usually not part of the rules provided within constitutions.

${ }^{4}$ For the purposes of constructing a measurable statistic, data has been collected to reflect the executive branch as a whole (President or Monarch and Prime Minister). This entails that in the construction of each indicator the rules for both the head of state and the head of government, if they differ, are taken into account where relevant. Given that PMs terms depend on the tenure of the government, the length of term variable is based on the term of the President. More details on the construction of the index are presented in the next section. 
Italian Constitution). Most other countries have a four or five year term, with the exception of Austria and Finland whose Presidents have a six year term in office.

The second indicator that is considered to affect legitimation is the confidence of people in their rules. This is reflected by the option to impeach the president, on the one hand, and the option for parliament, perceived of as people's agent which keeps a 'check' on government, to apply a vote of no confidence in the government. The logic here is intuitive - if there is an option to impeach, the people have more control, even if impeachment is achieved indirectly through parliament. Among European democracies, Cyprus, Switzerland and Poland are the only countries which do not provide a legal option for the removal of the head of state (in both Cyprus and Switzerland the head of state is also the head of government). The variation among the rest of Europe comes from the threshold for initiation of the procedure and votes needed for it to pass. The two most common barriers for the passing of a motion of no confidence are absolute majority or two-thirds majority. Some states, Greece is an example here, are even more liberal in that they allow a motion of no confidence to pass with a majority of those present (Art. 84. 2. 6, Greek Constitution); however, there is a minimum limit that at least two-fifths of the total number of MPs need to be present. Slovakia also presents an interesting case for the option to impeach. There, an impeachment motion can be initiated by three-fifths majority of all members of the National Council, but its actual adoption is brought to public voting. The President is recalled if more than one half of all eligible voters agree (Art. 106. 1 \& 2, Slovak Constitution). Although the Slovak constitution gives a lot of de jure power to the people, achieving the passage of a motion of threefifths of the legislature is quite a high threshold to surpass, which makes their de facto power not so much after all. Austria presents a similar case.

The presence of veto power and the conditions for veto override are also considered. The idea of the connection between legitimation and the right to veto implemented here is somewhat counterintuitive. Having in mind our point of departure, i.e. that we consider the more control people have over the actions of the executive, the more legitimate the latter will be, having no veto power at all, is the option which would legitimate the executive in the eyes of the people. Thus, while for other purposes we would consider veto power to be a generally beneficial characteristic to the system of checks and balances in a democracy, here the logic runs in the other direction. Veto override presents an interesting variation among European democracies. Nine out of the thirty studied countries do not provide the option of executive veto, or at least do not do so by their constitutional rules. These countries include Austria, Belgium, Denmark, Germany, Malta, the Netherlands, Sweden and Switzerland. Switzerland is in 
fact the only country where any citizen who can gather 50000 signatures can challenge a bill by the federal parliament and an initiative of 100,000 people can introduce a new amendment to the federal constitution. ${ }^{5}$ This sets Switzerland apart from most other countries not only in Europe, but in the world, as an example of a case with the highest possible level of direct democracy as can be. Another case worth mentioning is that of Norway. Among the European monarchies, Norway is the only one which gives its King the power to veto. According to Art. 78 of the Norwegian constitution, the King has the right not to sign a bill and return it to parliament. The Storting then has to pass the bill again, but it has to vote on it twice with at least two intervening sessions in between, after which the bill is returned to the King for signature asking him not to refute the bill again (Art. 79, Norwegian Constitution). ${ }^{6}$ The strongest veto power is manifested by the executives of Cyprus and Hungary. In Cyprus the President and the Vice-President of the Republic, separately or conjointly, have the right of final veto on any law or decision of the House of Representatives (Art. 50, Constitution of Cyprus). A less terminal, but still the second most power executive veto is that of the Hungarian President. According to Article 6 of the Hungarian Constitution:

(4) If the President of the Republic finds the Act or any constituent provision contrary to the Fundamental Law and no examination has been held under Paragraph (2), he or she shall send the Act to the Constitutional Court to examine its conformity with the Fundamental Law. (5) If the President of the Republic disagrees with the Act or any constituent provision and has not exercised his or her right under Paragraph (4), he or she may return the Act once to Parliament for reconsideration along with his or her comments before signature. Parliament shall hold a new debate on the Act and decide on its adoption again. (9) ... If Parliament adopts the Act returned due to any disagreement of the President of the Republic with the text unamended, the President of the Republic may propose that it should be examined for conformity with the Fundamental Law on the grounds of failure to meet the procedural requirements for the drafting of such Act.

All other European countries, with the exception of Croatia, have what we may term a 'typical' veto power of the executive, where, in most cases, the President, can return a bill for second voting, with a statement about which parts of the bill he or she does not agree with and why. Usually, this is considered more of a signal than real veto power, since if a bill has passed once, it is very likely

${ }^{5}$ Source: http://direct-democracy.geschichte-schweiz.ch/.

${ }^{6}$ While the role of the king of Norway may be said to be rather ceremonial, it is imperative that for the construction of the index presented here, he has the right not to sign a given bill. 
that given the voting majority hasn't altered in the time during which the bill was with the head of state, it will pass again. Croatia is the only European democracy where the President can 'initiate proceedings to review the constitutionality of the law before the Constitutional Court of the Republic of Croatia' (Art. 88, Constitution of Croatia), but without the specified right to call a second reading.

The next variable of interest is the direct election variable. The connection with legitimacy here is straight forward - providing the option to directly elect the two leading members of the executive branch, namely the head of state and head of government, gives most control to people over who their rulers are, and is thus considered to give the highest level of legitimation. There are eight European democracies which do not allow their citizenry to directly elect either of the two highest offices. In Estonia, Greece, Hungary, Italy, Latvia and Malta, it is the parliament who chooses the President of the country, while in Germany the President is elected by a special Federal Council. A unique case is presented by Switzerland and it special Federal Council. The latter is an institution chosen by both chambers of the assembly and consists of seven members, who take the Presidency on one-year rotational basis. The majority European states, allow their citizens to directly elect at least one of the two executive branch leaders, with the exception of the six monarchies, where the head of state is exercised by the monarch, in which case the post is hereditary, and the head of government is either chosen by parliament or by the monarch.

The number of terms in office and checks and balances on the concentration of power are the last two indicators considered. The logic here is that if the number of terms (of the head of state) is limited, then the people have more power to make a change if they are not happy with how they are being governed. Two-thirds of the European democracies studied here limit the number of terms that the head of state can take. All but Switzerland limit the terms to two; in Switzerland the limit is one. From the remaining ten democracies, six are the constitutional monarchies, and the other four are Cyprus, Iceland, Italy and Malta. Within that group only Iceland presents somewhat of a surprise, since as the other three countries do not leave much power to the people as seen in the previous variables discussed. In Iceland, on the other hand, Art. 11 of the Constitution posits that the President can be removed by a direct vote from the people, however after a resolution passed by three-fourths of the Althingi (parliament) members. One may reason however, that the fact that the President can be removed by the people explains why the constitutional engineers have not felt compelled to put a cap on the number of terms the head of state can serve.

The last indicator considered is the that for checks and balances. In this study checks and balances refers to who appoints the judiciary and more importantly, 
who appoints the president of the top court? The relationship between the judiciary and legitimation is that an independent judiciary, one that can serve as a check on the executive branch, would make the executive branch power to govern more legitimate in the eyes of the people. In that sense, the ideal scenario would be if people could choose the judiciary directly, an option, which indeed is non-existent. The second best option would be if the choice of the judiciary is 'outsourced' from the people either to an open contest or to an independent agency which can decide on behalf of the people. The constitutional analysis illustrates that Europe is quite equally divided when it comes to the election of the judiciary. While every constitution claims the independence of the judicial branch, a closer look at who decides about the key judicial posts in a given country, reveals three distinct groups of cases. The most liberal countries, those which select the top posts of their judiciary branch through independent agencies, are Denmark, France, Germany, Hungary, Norway, Poland, Slovakia and Sweden. In Denmark for example 'judges are appointed by the monarch upon the recommendation of the Minister of Justice with the advice of the Judicial Appointments Council, a 6-member independent body of judges and lawyers' (CIA Report Denmark, 2014). Similarly, in France 'Court of Cassation judges are appointed by the President of the Republic from nominations from the High Council of the Judiciary, presided by the Court of Cassation and 15 appointed members' (CIA report France, 2014). The proposals of nomination for the High Council of the Judiciary is a mix between the President, the Senate, the parliament and fellow judges - a diverse body of nominations, which signifies for the level of independence. ${ }^{7}$ The other twenty-two European democracies are equally divided between the judiciary been chosen by the parliament or by the executive branch. An interesting observation here is that most East-European states fall within the second category - where the judiciary is chosen by the parliament. This is important given that one of the largest criticisms of the European Commission towards its new member-states has been the independence of the judiciary. In that sense, Bulgaria, Croatia, Estonia, and Lithuania, still have quite a distance to go, as all four of them involve the executive branch in the decisions about key judicial posts.

\section{THE INDEX}

Despite the centrality that the concept of political legitimacy has in political science studies, there have been very few any attempts to quantify it and create a measurable statistic (Gilley 2006, 2012 is a notable exception). Gilley has pioneered in developing a quantitative measurement of political legitimacy,

${ }^{7}$ http://www.law.uchicago.edu/files/files/250-444.pdf 
despite the pessimistic view of Easton (1965, cited in Gilley 2006) and King (1994, cited in Gilley 2006) about the prospects of the measurement of such an abstract concept. Nevertheless, he embarks on the task and produces a quantified measure of political legitimacy for 72 countries around the world. His measure focuses however, on what has been termed by Schmidt (2013) 'output' legitimacy. Despite trying to integrate his measure within Beetham's threedimensional framework, all indicators which he uses are indicators of 'reaction' to the political system. For instance, he divides potential indicators of legitimacy into attitudes and actions and offers several examples for legality, justification, and consent. Yet, virtually all of his examples involve survey data on attitudes and acceptance, or data on movements, electoral turnout, or tax payments. Here, as argued in the theoretical section, the approach is somewhat different. The Executive Legitimation Index (ELI) offered in this study is built on the basis of the legal roots of legitimacy - specifically, on the rules which societies created in order to legitimate power. In this sense, the index reflects the first component of legitimacy - legitimation, while Giley's measurement would fall better within the third component of legitimacy as developed here - evaluation. Each has its merits and its drawbacks. The contribution of the ELI is in that it allows a 'mapping' of the rules which vest power in our governments and it can be very useful for evaluating the second and the third component of legitimacy, namely the delivery and the evaluation parts of the concept. Additionally, the ELI index can lend itself to all regime types and can serve as a benchmark criteria for new democracies - for example, in their constitutional design.

To construct the index, data on the seven indicators outlined in the previous section has been collected from the Constitutional texts of thirty European democracies. The 'raw' data was then coded and transformed into a single measurable statistic. All variables were given numerical values between 0 and 4 , in order to create a balanced index, where each of the seven indicators has the same weight. Thus, a higher score would signify that the people have more power in removing the executive and would thus stand for higher level of legitimation, and a lower score would signify that people have less power and therefore the legitimation component of the legitimacy concept is lower. The years in office variable was coded 0 to signify that the executive term is seven years or larger - the outcome furthest from the people's ability to initiate change, 1 for a term of 6 years, 2, for a term of 5 years, 3 for a term of 4 years, and 4 for a term of less than four years. The mean score for the studied sample of countries for this variable is 2.13 , suggesting that the average term of the executive is between four and five years. The confidence variable was coded with values of 0 for being 'as far from the people as possible' with no option to impeach, nor an option of a vote of no confidence, and 4 signifying the strongest control people have on the executive 
branch, by a constitutionalized option to impeach and the potential to pass a no confidence motion with a one parliamentary half majority (given that the parliament is the representation of people in politics, having the lowest possible threshold by which an unsatisfactory leader can be asked to step down is considered the option which gives most power to the people and thus is awarded the highest legitimation score). The average score here is 2.67 , indicating that on this particular variable most constitutions tend to lean toward giving more power to the people. For veto override and direct election a country receives a score of 4 if it has direct election for both of its heads of the executive branch, and if the head of state has no veto power. The lowest scores are given to states with terminal veto option for the head of state and when neither of the two main leaders is directly elected. The respective averages here are 2.09 for the veto override variable and 1.73 for direct election. These statistics signify that to a large extent European constitutional rules vest a lot of powers in the executive branch. The final two variables which are included in the index, number of terms and checks \& balances, are coded 0,2 and 4. A country would receive a score of 4 if the number of terms of the head of state are less than or equal to two, and if the judiciary is appointed by an independent agency. Conversely, scores of 0 are assigned if there is no limit on the number of terms for the head of state, and if the judiciary is appointed by the executive branch. The mean scores here are 2.67 for the number of terms and 1.8 for the checks \& balances, suggesting that on the second indicator European states have more room to change if they want to increase their legitimacy vis-à-vis the people that give them the power to rule. All details of the coding rules are summarized in the Appendix.

The index is constructed by summing the score of all categories per country and dividing that number by the highest attainable score. The result is an index with values between 0 and 1, 1 signifying highest attainable legitimation by the rules. The aggregated ELI index and the highest scoring category per country are presented in Table 1. 
Table 1: Highest scoring category and ELI index.

\begin{tabular}{|c|c|c|c|c|c|c|c|c|}
\hline Country & Years & Confidence & Veto & $\begin{array}{c}\text { Direct } \\
\text { Election }\end{array}$ & Decree & Terms & Checks & \begin{tabular}{|c} 
Executive \\
Legitimation \\
Index
\end{tabular} \\
\hline Austria & & & $\checkmark$ & & & & & 0.67 \\
\hline Belgium & & & $\checkmark$ & & $\checkmark$ & & & 0.55 \\
\hline Bulgaria & & & & & & $\checkmark$ & & 0.54 \\
\hline Croatia & & & & & & $\checkmark$ & & 0.58 \\
\hline Cyprus & & & & $\checkmark$ & $\checkmark$ & & & 0.36 \\
\hline $\begin{array}{c}\text { Czech } \\
\text { Republic }\end{array}$ & & $\checkmark$ & & & & $\checkmark$ & & 0.64 \\
\hline Denmark & & & $\checkmark$ & & & . & $\checkmark$ & 0.55 \\
\hline Estonia & & $\checkmark$ & & & & $\checkmark$ & & 0.48 \\
\hline Finland & & & & & & $\checkmark$ & & 0.50 \\
\hline France & & & & & $\checkmark$ & $\checkmark$ & $\checkmark$ & 0.71 \\
\hline Germany & & & $\checkmark$ & & & $\checkmark$ & $\checkmark$ & 0.68 \\
\hline Greece & & & & & & $\checkmark$ & & 0.51 \\
\hline Hungary & & & & & & $\checkmark$ & $\checkmark$ & 0.54 \\
\hline Iceland & $\checkmark$ & $\checkmark$ & & & & & & 0.43 \\
\hline Ireland & & & $\checkmark$ & & $\checkmark$ & $\checkmark$ & & 0.63 \\
\hline Italy & & $\checkmark$ & & & & & & 0.33 \\
\hline Latvia & & & & & $\checkmark$ & $\checkmark$ & & 0.62 \\
\hline Lithuania & & $\checkmark$ & & & $\checkmark$ & $\checkmark$ & & 0.64 \\
\hline Malta & & $\checkmark$ & $\checkmark$ & & $\checkmark$ & & & 0.50 \\
\hline Netherlands & & & $\checkmark$ & & $\checkmark$ & & & 0.58 \\
\hline Norway & & & & & & & $\checkmark$ & 0.41 \\
\hline Poland & & & & & $\checkmark$ & $\checkmark$ & $\checkmark$ & 0.71 \\
\hline Portugal & & $\checkmark$ & & & & $\checkmark$ & & 0.57 \\
\hline Romania & & & & & & $\checkmark$ & & 0.61 \\
\hline Serbia & & & & & $\checkmark$ & $\checkmark$ & & 0.64 \\
\hline Slovakia & & $\checkmark$ & & & $\checkmark$ & $\checkmark$ & $\checkmark$ & 0.79 \\
\hline Slovenia & & & & & & $\checkmark$ & & 0.61 \\
\hline Spain & $\checkmark$ & & & & & & & 0.42 \\
\hline Sweden & & & $\checkmark$ & & $\checkmark$ & & $\checkmark$ & 0.65 \\
\hline Switzerland & $\checkmark$ & & $\checkmark$ & & & $\checkmark$ & & 0.57 \\
\hline Total \# & 3 & 8 & 9 & 1 & 12 & 19 & 8 & \\
\hline W. Europe & & & & & & & & 0.53 \\
\hline E. Europe & & & & & & & & 0.62 \\
\hline
\end{tabular}


As can be clearly seen from the check marks in Table 1, the terms variable has received the highest score in a majority of the European states studied here. This shows that among the included categories, country rules tend to be most liberal on this category. The second most liberal category is decree suggesting that European democracies tend to give more power to the people by limiting the ability of the executive to rule by decree. Finally, the category which is least prone to liberalization is direct election. The fact that we see only a single check mark there implies that, overall, states are more liberal on the other six categories than they are on the direct election one. The values of the ELI index are reported in the last column in Table 1 and are visually presented in a map in Figure 2.

Figure 2: Constitutional legitimation of the executive branch in post-war Europe.

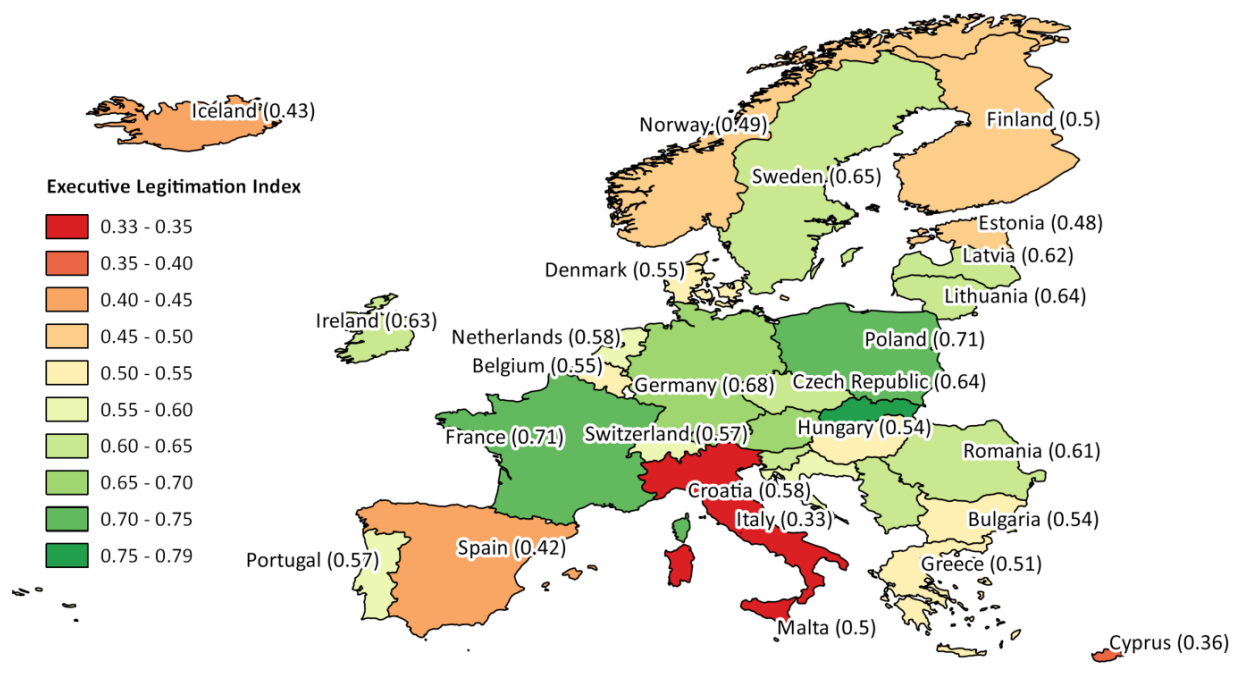

Source: Author's calculations.

The map in Figure 2 illustrates the distribution of the ELI index which is between 0.33 and 0.79. Countries represented in dark orange, in this case Cyprus, Italy and Spain, are at the bottom of the ladder, countries represented in green and dark green are at the top. The state with highest executive legitimation score is Slovakia, which has an index of 0.79 . When we look at Slovakia's regulation record, what appears evident is that it is a country which has adopted moderate 
positions. For example, the length of the head of state term is 5 years, limited to two terms; the executive does not have decree power and can be impeached, and the impeachment is done by popular vote; the head of state is directly elected and the government can be taken down with a majority of all MPs; finally, key posts in the judiciary are selected by an independent agency. ${ }^{8}$ The lesson that we can take from here is that being moderate, pays off.

Next to developing the index, the paper offers several two sample t-tests to examine whether there are significant differences in executive regulation among four distinct groups of interest. Following Biezen and Rashkova (2014) and Biezen and Borz (2012), the dichotomous groups of interest are - Eastern vs. Western Europe, New vs. Old Democracy, Continuous vs. Discontinuous Democracy, and Monarchy vs. Republic. The results from this analysis are reported in Table 2.

Table 2: ANOVA tests of significant differences in executive regulation in European democracies

\begin{tabular}{ccccc}
\hline Category & $\begin{array}{c}\text { Eastern / } \\
\text { Western Europe }\end{array}$ & $\begin{array}{c}\text { New / Old } \\
\text { Democracy }\end{array}$ & $\begin{array}{c}\text { Continuous / } \\
\text { Discontinuous } \\
\text { Democracy }\end{array}$ & $\begin{array}{c}\text { Monarchy / } \\
\text { Republic }\end{array}$ \\
\hline Years in office & $0.31(0.76)$ & $0.00(1.00)$ & $-0.10(0.92)$ & $-6.41(0.00)^{* * * \wedge}$ \\
Impeachment / confidence & $-2.33(0.03)^{* *}$ & $-2.46(0.02)^{* *}$ & $1.54(0.14)$ & $4.06(0.00)^{* * *}$ \\
Veto override & $3.27(0.00)^{* * *}$ & $3.70(0.00)^{* * *}$ & $-3.63(0.00)^{* * *}$ & $-2.07(0.08)^{*}$ \\
Direct election & $-0.98(0.34)$ & $-0.59(0.56)$ & $0.78(0.44)$ & $1.83(0.08)^{* \wedge}$ \\
Executive decree & $0.15(0.89)$ & $1.09(0.28)$ & $-0.99(0.33)$ & $-0.34(0.74)$ \\
Number of terms in office & $-4.61(0.00)^{* * *}$ & $-3.63(0.00)^{* * *}$ & $3.07(0.00)^{* * *}$ & $10.7(0.00)^{* * * \wedge}$ \\
Checks \& balances & $-0.09(0.93)$ & $0.22(0.82)$ & $-0.13(0.89)$ & $-2.72(0.02)^{* *}$ \\
\hline Total Magnitude & $-2.08(0.05)^{* *}$ & $-1.21(0.24)$ & $0.84(0.41)$ & $0.79(0.44)$ \\
\hline Nof observations & 12.18 & $15 / 15$ & $13 / 17$ & 6.24 \\
\hline
\end{tabular}

Note: Two-sample t-test with unequal variances. T-statistic reported, $\mathrm{p}$-value in parentheses; ${ }^{*} \mathrm{p}<0.1, \mathrm{p}^{* *}<0.05, \mathrm{p}^{* * *}<0.01$. ${ }^{\wedge}$ Some data were checked with the Mann-Whiteney U test, due to their non-normal distribution. The results which differed from the t-tests are reported.

\footnotetext{
${ }^{8}$ Supreme Court judge candidates is proposed by the Judicial Council of the Slovak Republic, a 17-member independent body to include the Supreme Court chief justice and presidential and governmental appointees; (CIA report Slovakia, 2014). More on the appointment of the Judicial Council is available here: http://www.sudnarada.gov.sk/data/files/526_act-185-on-the-judicialcouncil-of-the-slovak-republic.pdf.
} 
The output in Table 2 confirms, to a large extent, what has been shown so far. We see for example, that there is a high statistically significant difference in the length of the executive term, the impeachment procedure and the checks and balances between monarchies and republics - a result which is hardly surprising, given that in monarchies the term of the head of state is unlimited, the monarch cannot be removed, and that in at least one case, it is the monarch who appoints the key positions of the judiciary. There is also a clear difference in the regulation of the executive branch in terms of its rules pertaining to the impeachment and no confidence procedures and the option to veto, as well as the thresholds on veto override, between Eastern and Western Europe and New and Old Democracies. This is a confirmation of the substantive data, which shows that West and Old European democracies have more liberal rules on the ability of the executive to place a veto and on the rules to override it.

\section{CONCLUDING REMARKS}

Current protests against the ruling elite in many countries of the world put to question the legitimacy of political power. An elusive, yet a very widely used concept, political legitimacy remains one of the most important factors for all political players, as well as for academics studying political actors and their behavior. We have however, surprisingly few attempts to quantify it, such that when one speaks of political legitimacy in one place, it can be easily and reliably compared to what we think of political legitimacy at another. Attempting to fill this gap, and complementing Gilley (2006), this paper develops an index of political legitimation, and more specifically of the legitimation of the executive branch. Here, legitimacy is conceived of as containing three parts - legitimation, delivery, and evaluation. Relying on primary data gathered from the Constitutional texts of individual countries, the study offers a new measure - the Executive Legitimation Index (ELI) - for thirty European democracies. The ELI index allows us to compare the level of legitimation that different rules provide and draw conclusions for future institutional engineering or reforms. It also provides a new variable, a measurable statistic of political legitimacy, which can be used in further studies trying to explain the political legitimacy of a given country or a set of countries, or it can be explained in itself. An interesting question to pursue further is the link between how liberal (in terms of legitimation) the rules for the executive are, given other characteristics of the political arena - for example, do countries with more fragmentized party system tend to be more strict on people's control and power over the removal of the executive, or are states which have more women in politics more liberal. Additionally, the index can be expanded to 
include not only the democracies of Europe, but also other regions of the world.

\section{REFERENCES}

Beetham, David. 1991. The Legitimation of Power. Basingstoke: Palgrave.

Biezen, Ingrid van. 2013. Party Law in Modern Europe. Database available at http://www.partylaw.leidenuniv.nl/

Biezen, Ingrid van. 2004. "Political Parties as Public Utilities", Party Politics, 10 (6): 701-722.

Biezen, Ingrid van and Gabriella Borz. 2012. "Models of party democracy: patterns of party regulation in post-war European constitutions", European Political Science Review, 4 (3): 327-359.

Biezen, Ingrid van and Petr Kopecky. 2007. "The State and the Parties:

Public Funding, Public Regulation and Rent-Seeking in Contemporary Democracies." Party Politics, 13 (2): 235-254.

Biezen, Ingrid van, and Ekaterina R. Rashkova. 2014. "Deterring New Party Entry? The Impact of State Regulation on the Permeability of Party Systems", Party Politics. 20 (6): 890-903.

Biezen, Ingrid van and Helen Wallace. "Old and New Oppositions in Contemporary Europe", Government and Opposition, 48 (3): 289-313.

Casal-Bértoa, Fernando, Daniela Piccio and Ekaterina Rashkova. 2014a. "Party Laws in Comparative Perspective: Evidence and Implications" in I. van Biezen and H. ten Napel (eds.), Political Parties and Public Law, Leiden University Press.

Casal Bértoa, Fernando, Fransje Molenaar, Daniela R. Piccio and Ekaterina R. Rashkova. 2014b. "The World Upside Down: De-Legitimizing Political Finance Regulation”, International Political Science Review, 35 (3): 355376.

Gauja, Anika. 2014. "Building Competition and Breaking Cartels? The Legislative and Judicial Regulation of Political Parties in Common Law Democracies", International Political Science Review, 35 (3): 339-354.

Gherghina, Sergiu. 2014. "Shaping Parties' Legitimacy: Internal Regulations and Membership Organizations in Post-Communist Europe", International Political Science Review, 35(3): 291-306.

Gilley, Bruce. 2006. "The Meaning and Measure of State Legitimacy: Results for 72 countries", European Journal of Political Research, 45: 499-525.

Gilley, Bruce. 2012. "State Legitimacy: An updated dataset for 52 countries", European Journal of Political Research, 51: 693-699.

Heritier, Adrienne. 1999. "Elements of democratic legitimation in Europe: an 
alternative perspective", Journal of European Public Policy, 6 (2): 269-282. Katz, Richard S. and Peter Mair. 1995. "Changing Models of Party Organization and Party Democracy: The Emergence of the Cartel Party", Party Politics 1 (1): 5-28.

Molenaar, Fransje. 2014. "Legitimizing political party representation: Party law development in Latin America", International Political Science Review, 35 (3): 324-338.

Moravcsik, Andrew. 2002. 'In Defense of the 'Democratic Deficit': Reassessing Legitimacy in the European Union", Journal of Common Market Studies, 40 (4): 603-624.

Rashkova, Ekaterina R, and Ingrid van Biezen. 2014. "The Legal Regulation of Political Parties: Contesting or Promoting Legitimacy?", International Political Science Review,35 (3): 265-274.

Rothstein, Bo. 2009. "Creating Political Legitimacy: Electoral Democracy versus Quality of Government", American Behavioral Scientist, 53 (3): 311-330.

Scherlis, Gerardo. 2014. "Political Legitimacy, Fragmentation, and the Rise of Party-Formation Costs in Contemporary Latin America", International Political Science Review, 35 (3): 307-323.

Schmidt, Vivien A. 2013. "Democracy and Legitimacy in the European Union Revisited: Input, Output and Throughput”, Political Studies, 61 (2): 2-22. Svåsand, Lars. 2014. "Regulations of political parties and party functions in Malawi: incentive structures and the selective application of the rules", International Political Science Review, 35 (3): 275-290.

Whiteley, Paul. 2014. "Does Regulation Make Political Parties More Popular? A Multi-level Analysis of Party Support in Europe", International Political Science Review, 35 (3): 376-399. 
Appendix: Coding Scheme

\begin{tabular}{|c|c|c|}
\hline Indicator & Coding / Measure & Mean score \\
\hline Years in office & $\begin{array}{l}<4 \rightarrow 4 \\
=4 \rightarrow 3 \\
=5 \rightarrow 2 \\
=6 \rightarrow 1 \\
>=7 \rightarrow 0\end{array}$ & 2.13 \\
\hline $\begin{array}{c}\text { Impeachment / vote of no } \\
\text { confidence }\end{array}$ & $\begin{array}{c}\text { Impeachment } / \text { no conf. } \\
\text { passed by } 1 / 2=4 \\
\text { Impeachment } / \text { no conf. } \\
\text { passed by } 2 / 3=3 \\
\text { No impeachment } / \text { no } \\
\text { conf. passed by } 1 / 2=2 \\
\text { No impeachment } / \text { no } \\
\text { conf. passed by } 2 / 3=1 \\
\text { Not available }=0\end{array}$ & 2.67 \\
\hline Veto override & $\begin{array}{c}\text { None }=4 \\
\text { Weak veto }(\text { second } \\
\text { reading, checking } \\
\text { constitutionality })=2.67 \\
\text { Veto }(\text { override by } 1 / 2)= \\
1.33 \\
\text { Strong terminal veto }=0\end{array}$ & 2.9 \\
\hline Direct election & $\begin{array}{c}\text { Yes } / \text { yes }=4 \\
\text { Yes } / \text { no; no } / \text { yes }=2.67 \\
\text { Hereditary } / \text { no }=1.33 \\
\text { No } / \text { no }=0\end{array}$ & 1.73 \\
\hline Executive decree & $\begin{array}{l}\text { No }=4 \\
\text { Yes }=2\end{array}$ & 2.87 \\
\hline Number of terms & $\begin{array}{c}<=2 \rightarrow 4 \\
>2 \text {, but limited } \rightarrow 2 \\
\text { Unlimited } \rightarrow 0\end{array}$ & 2.67 \\
\hline Checks \& balances & $\begin{array}{c}\text { By open contest or an } \\
\text { independent agency }=4 \\
\text { By parliament }=2 \\
\text { By President } / \text { King }=0\end{array}$ & 1.80 \\
\hline
\end{tabular}

